In sum, the travel writings by Brasseur offer a necessary complement not only to his accomplishments as a scholar but also to a deeper understanding of the birth of modern Mesoamerican studies.

Independent Scholar

Alessia Frassani

Mexico City, Mexico

alessiaf@ymail.com

\title{
INEQUALITY AND CITIES
}

Urban Latin America: Inequalities and Neoliberal Reforms. Edited by Tom Angotti. Lanham, MD: Rowman and Littlefield, 2017. Pp. 299. \$89.00 cloth; \$35.00 paper. doi:10.1017/tam.2018.71

This text offers a valuable overview of development problems, neoliberal reforms, and struggles of social movements in Latin American cities. It is useful for researchers and for teaching undergraduate and graduate courses in Latin American urban politics, development, and planning. Through innovative case studies, the book explores the consequences of neoliberal urban reforms in a wide variety of Latin American cities with high levels of poverty and social inequality: Sao Paulo, Mexico City, Medellín, Bogotá, Rio de Janeiro, and Santiago de Chile, among others.

As with other books of the series Latin American Perspectives in the Classroom, most of the chapters are not original: of the 16 chapters that comprise this text, 12 were already published (the majority in the journal Latin American Perspectives), or based on other previous publications. The sections of the book are unequal with respect to their quality, as well as in their critical contribution to the understanding of the impacts of neoliberal reforms in the persistence of poverty and inequality.

In the first chapter, an introduction, Angotti suggests that in Latin America, the cause of poverty, inequality, informality, violence, and enclaves among other urban problems should be found in dependent capitalism development and the globalization of capital. He recommends looking beyond the cities to understand the complexity of urban problems and the social, economic, and political forces that cause them, so as to analyze "all urban neighborhoods as complex communities that are part of a larger capitalist political economy, both local and global” (4). The second chapter, written by Alan Gilbert, presents data on poverty, inequality, and other problems of Latin America. Gilbert offers statistical information about employment in the informal sector for the years 2014 and 2015, showing that Bolivia has the highest percentage of employment in the informal sector and that in the same respect Venezuela is above the median for Latin America. However, he does not explain why these countries have such a high percentage of people working in the informal sector. Given that they both applied anti-neoliberal urban policies, and that informality is generally supposed to be the 
consequence of the implementation of neoliberal policies, this seems an omission. Gilbert also compares the Gini index of household income inequality for Latin America and the Caribbean region with that of other world regions. He uses this index without taking into account that some of the countries included in the Latin American index did implement anti-neoliberal policies to face income inequality; he could have compared the differential effects of applying neoliberal or anti-neoliberal policies on income inequality.

Diane Davis's excellent "Globalization, Governance, and the Collision of Forces in Mexico City's Historic Center" (Chapter 6) is perhaps one of the four previously unpublished chapters of the book that makes an innovative contribution to the text. By analyzing the Alameda Project, a controversial urban development located in Mexico City's center, this chapter explains how the global and local forces have articulated, coalesced, and diverged, as well as their interaction with urban social movements. She shows how a combination of unanticipated historical, cultural, and economic forces at the local level affected the spatial pattern of Mexico City's historic center "in ways not originally anticipated by proponents of urban development" (80). Other interesting contributions (originally published in Latin American Perspectives (issue 44) are the chapters written by Tobias Franz (Chapter 9) and by Stacey Hunt (Chapter 10). Using empirical data, these authors critically evaluated two "so-called" best practices. They showed the achievements and shortcomings of the social urbanism and economic development of the "miracle" in Medellín and put into question the claimed functionality of the Transmilenium, considered as one of Bogotá s transportation landmarks.

The book includes the experience of housing and urban development in Cuba as an "Exception to the Rule" (Chapter 12). This chapter, written by Jill Hamberg, is highly descriptive; she gives a historical account of housing policies and urban development in Cuba, and claims: "Most people in Cuba have secure tenure to their home and do not face displacement" (186). Nonetheless, although she mentions the "new realities and challenges" of the post-Castro years (186) such as housing deficit, the author does not explain well enough the causes of what she calls the "challenges ahead" (197) and leaves aside issues of freedom and participation in decision-making on urban policies at the national and regional levels. Moreover, despite the active and important economic relationship between Cuba and Venezuela, which dates from 1999, Hamberg does not discuss its impact on the transition to the post-Castro era.

The last three chapters $(14,15$ and 16) interpret urban mobilizations as struggles against neoliberalism to advance citizenship rights. Open to question is whether they are really protests against neoliberalism-they also occur in Latin American countries with anti-neoliberal agendas. One example is the recent urban struggle in Venezuela against the government of Nicolas Maduro for the right to food, medicine, electricity, water, and other basic community and social services. Another example is the struggle against extractivism in Bolivia, Ecuador, and Venezuela. 
The lack of analysis of anti-neoliberal and anti-globalization urban experiences that have emerged in Latin America in the last 18 years, as in the cases of Bolivia, Ecuador, and Venezuela, is an important void in the book. These experiences represent a valuable and unique opportunity to evaluate more comprehensively the relationships among neoliberalism, globalization, poverty, inequality, and other urban problems in Latin America. Many urban problems discussed in the book, presented as the consequence of urban neoliberal reforms, occur also in Latin American cities representing the so-called "Socialism of the Twenty-First Century."

Moreover, sustainability of the anti-neoliberal policies against poverty and urban inequality largely depends on an economic boom based on ever greater extraction. Anti-neoliberalism has not been able to get rid of extractivism, which in turn, is supported by the globalized economy, causing serious problems in environmentally and socioculturally vulnerable areas such as the isolated rural populations and indigenous communities.

Universidad Simón Bolivar

MARÍA PILAR GARCÍA-GUADILLA

Caracas, Venezuela

mpgarcia@usb.ve

\section{US-MEXICO BORDERLANDS}

The Lynching of Mexicans in the Texas Borderlands. By Nicholas Villanueva Jr. Albuquerque: University of New Mexico Press, 2017. Pp. xii, 219. Illustrations. Notes. Bibliography. Index. $\$ 55.00$ cloth.

doi:10.1017/tam.2018.72

Texas stands out as a state with a long history of discrimination against minorities, in particular people of Mexican origin. The 1910s was an especially difficult decade for this ethnic group because racist sentiments among white Texans of European background often deteriorated into violent attacks against Mexicans. Several factors account for the intense anti-Mexican sentiment: prejudice against dark-skinned people; prejudice against Catholics; protracted conflict between Mexico and the United States that often spilled over the Rio Grande; alarm over the anti-Americanism that flared up in Mexico during that country's civil war, known as "La Revolución"; and suspicions that Mexican Americans were not sufficiently loyal to the United States. These suspicions flared especially high during the US intervention in the city of Veracruz in 1914; the 1916 U.S. military incursion into the state of Chihuahua following Pancho Villa's attack on Columbus, New Mexico; and during World War I, when German agents operated along the US-Mexico border.

Villanueva devotes considerable space to contextualizing the violence perpetrated against Mexicans and Mexican Americans. He provides background on native Tejanos as well as Mexican migrants, refugees, and exiles, and he highlights the uneasy relations of these subgroups with the dominant population. The author also describes social conditions 